\title{
Monitoring of Vegetation Disturbance around Protected Areas in Central Tanzania Using Landsat Time-Series Data
}

\author{
Atupelye W. Komba ${ }^{1, *(\mathbb{D})}$, Teiji Watanabe ${ }^{2} \mathbb{D}$, Masami Kaneko ${ }^{3}$ and Mohan Bahadur Chand ${ }^{2} \mathbb{D}$ \\ 1 Graduate School of Environmental Science, Hokkaido University, Sapporo 060-0810, Japan \\ 2 Faculty of Environmental Earth Science, Hokkaido University, Sapporo 060-0810, Japan; \\ twata@ees.hokudai.ac.jp (T.W.); mohanchand06@gmail.com (M.B.C.) \\ 3 College of Agriculture, Food and Environment Sciences, Rakuno Gakuen University, Ebetsu 069-8501, Japan; \\ kaneko@rakuno.ac.jp \\ * Correspondence: atupelyek@eis.hokudai.ac.jp; Tel.: +81-70-2663-3550
}

check for updates

Citation: Komba, A.W.; Watanabe, T.; Kaneko, M.; Chand, M.B. Monitoring of Vegetation Disturbance around Protected Areas in Central Tanzania Using Landsat Time-Series Data. Remote Sens. 2021, 13, 1800. https:// doi.org/10.3390/rs13091800

Academic Editor: Todd Robinson

Received: 23 March 2021

Accepted: 28 April 2021

Published: 5 May 2021

Publisher's Note: MDPI stays neutral with regard to jurisdictional claims in published maps and institutional affiliations.

Copyright: (c) 2021 by the authors. Licensee MDPI, Basel, Switzerland. This article is an open access article distributed under the terms and conditions of the Creative Commons Attribution (CC BY) license (https:// creativecommons.org/licenses/by/ $4.0 /)$.

\begin{abstract}
Understanding vegetation disturbance around protected areas (PAs) is critical as it significantly affects the sustainable conservation of wildlife. However, there is a lack of analyses of consistent long-term data on vegetation disturbance. In this study, the LandTrendr algorithm and Google Earth Engine were used to access satellite data and explore the vegetation dynamics history across the Ruaha-Rungwa landscape, Tanzania. We characterized vegetation disturbance patterns and change attributes, including disturbance occurrence trends, rate, and severity, by using each pixel's normalized burn ratio index time series. Between 2000 and 2019, 36\% of the vegetation was significantly disturbed by anthropogenic activities. The results of this study show that the disturbance trends, severity, and patterns are highly variable and strongly depend on the management approaches implemented in the heterogeneous landscape: Ruaha National Park (RNP), Rungwa-Kizigo-Muhesi Game Reserves (RKMGR), and the surrounding zones. The disturbance rates and severity were pronounced and increased toward the edges of the western RKMGR. However, the disturbance in the areas surrounding the RNP was lower. The characterization of the vegetation disturbance over time provides spatial information that is necessary for policy makers, managers, and conservationists to understand the ongoing long-term changes in large PAs.
\end{abstract}

Keywords: vegetation disturbance; LandTrendr algorithm; Landsat time-series data; conservation; savannah; anthropogenic activity

\section{Introduction}

The establishment of protected areas (PAs) and the restriction of anthropogenic activities within PAs are considered to be the most successful and globally implemented measures to conserve endangered ecosystems [1-3]. However, anthropogenic habitat loss and disturbance have been identified as the key drivers of the biodiversity crisis occurring at the edge of PAs [4-6]. In recent decades, many terrestrial PAs have rapidly become isolated and shrunk due to the conversion of natural habitats into permanent and semipermanent cultivation land, logging, overgrazing, and land development [4,7-10], raising questions about whether PAs have been effectively implemented. Globally, anthropogenic activities have directly disturbed the structure and composition of ecosystems [11] in addition to the natural disturbance of vegetation patterns [12]. Generally, PA management approaches have the potential to affect the health status of ecosystems and landscape structures which leads to subsequent disturbances [1]. Considering the rapid population growth, the estimated growing demand in agricultural land [13,14], and the estimated future decline in vegetation due to climate change [15], increasing the resilience of PAs to vegetation disturbances through increased understanding is of high priority. In this context, the collection and analyses of scientific data, including the spatial extent, changing pat- 
terns, and effects of landscape changes, are critical for the implementation of appropriate conservation measures.

Understanding the vegetation dynamics and the advancement of cost-effective management approaches in an ecosystem require accurate information about current disturbance patterns $[16,17]$. The accessibility of extensive remote sensing data at different temporal and spatial scales has provided practical solutions and techniques for the longterm monitoring of disturbances, from the local to the global scale [18-20]. Time-series analysis using algorithms is one of the techniques employed to evaluate vegetation changes through the use of imagery $[18,21,22]$. It has been proven that the Landsat-based detection of disturbance trends using recovery algorithms or LandTrendr can capture vegetation dynamics at different capacities [23-26]. This approach allows users to segment each annual Landsat pixel time series into linear features from which a set of metrics can be obtained. Based on the use of these metrics, prevailing disturbance patterns can be revealed. Disturbance patterns describe the cumulative effects of the change in events, as well as their extent, occurrence rate, and magnitude/severity occurring in a given area over time [16].

Regarding terrestrial PAs, the native vegetation cover is a vital component providing habitat and forage to sustain wildlife populations. For instance, 55\% of the landscape in Sub-Saharan Africa is covered by the savannah biome [27], which is a region of global conservation importance. The African savannah supports some of the remaining long-range migrations of herbivores on Earth [28] and hosts the highest populations of ungulates and associated predators [29]. In Africa, savannah dynamics are controlled by anthropogenic and natural disturbances [30,31]. Human land use has led to the expansion of millions of hectares of cultivated land at the expense of the savannah and biodiversity [32]. Although $\sim 13.5$ million $\mathrm{km}^{2}$ of savannah in Africa is legally protected [33], most of the wildlife, at least partially, depends on land surrounding PAs. Migratory ungulate populations such as $\sim 1,300,000$ wildebeest (Connochaetes gnou) of the Serengeti-Mara ecosystem spend considerable periods outside PAs [34] in Kenya and Tanzania and large numbers of zebra (Equus burchelli) roam between the Okavango Delta and Makgadikgadi grasslands in Botswana [35]. It is becoming increasingly difficult for wildlife to cross the borders of PAs because large farming populations are replacing nomadic pastoralists at the edges [28]. The increase in agricultural land from $48 \mathrm{~km}^{2}$ in the $1970 \mathrm{~s}$ to $>500 \mathrm{~km}^{2} 20$ years later [36] around Kenya's Mara Game Reserve is a typical example of the expansion of cultivated land in the surrounding areas of PAs, which is associated with sharp declines in wildlife populations [37].

The Ruaha-Rungwa landscape (Ruaha National Park, RNP; Rungwa-Kizigo-Muhesi Game Reserves, RKMGR; wildlife management areas and surrounding unprotected habitat), Tanzania, is one of the largest ecologically intact savannah ecosystems remaining in Africa and is globally renowned for its outstanding species endemism and large populations of herbivores and carnivores [38]. In recent decades, the integrity of this ecosystem has been challenged by the increase in anthropogenic activities due to immigration and the rapidly growing human population, which predominantly depend on natural resources. In addition, the switch from traditional pastoral societies to sedentary lifestyles $[39,40]$ and increased land conversion into crops [41] have altered the rate and spatial patterns of vegetation disturbance in the landscape. Moreover, there is a lack of quantitative information about the disturbance patterns and their changes over time. Previous studies have focused on human-wildlife conflicts [42-44]. However, they lack spatially and temporally consistent data at the landscape scale. Based on this lack of quantitative data, it is difficult to determine the extent of the disturbance, and trends vary across the Ruaha-Rungwa landscape. Furthermore, recent studies have indicated an increase in human-wildlife conflicts across the edges of PAs $[28,42,44]$, but it remains unknown whether this change is related to the increasing disturbance rates (i.e., more disturbance events) or disturbance extent (i.e., larger disturbance patches). Similarly, our quantitative knowledge of the changes in the disturbance severity is limited and it remains unclear whether the landscape disturbance has become more severe in recent decades (e.g., through increased crop cultivation) or 
whether established management approaches (e.g., the adoption of wildlife management areas in surrounding zones) have reduced the disturbance severity.

To address these shortcomings, we mapped and characterized the historical vegetation disturbance patterns of the Ruaha-Rungwa landscape for the period 2000-2019. We addressed the following four questions: (1) What are the occurrence patterns, rates, and severity of vegetation disturbances across the landscape? (2) Has there been a trend in vegetation disturbance over the past two decades and how does it correlate with different management approaches across the landscape? (3) Is there a difference in the disturbance patterns within PAs and the surrounding zones? (4) Does the LandTrendr algorithm have the capability to rigorously detect changes in the normalized burn ratio (NBR) as an indicator for changes in the savannah? We addressed these research questions by mapping the occurrence and severity of vegetation disturbances in the Ruaha-Rungwa landscape. We used atmospherically corrected level-1 Landsat time-series images at a $30 \mathrm{~m}$ spatial resolution to characterize and analyze the conceptual models of the trajectories of spectral features in response to savannah disturbance as the basis for extracting vegetation changes over time at the landscape scale. Subsequently, a quantitative baseline was generated to understand the current vegetation changes in the Ruaha-Rungwa landscape.

\section{Materials and Methods}

\subsection{Study Area}

The Ruaha-Rungwa landscape covers an area of $\sim 50,000 \mathrm{~km}^{2}$ in southwest Tanzania and includes fully and partially protected as well as unprotected areas. At the heart of the ecosystem (Figure 1a), the RNP with an area of 20,226 km² was established in 1964 by the Tanzania National Parks Authority (TANAPA). The northern part of the ecosystem comprises the RKMGR, which were established between 1951 and 1995. These three game reserves occupy an area of $17,340 \mathrm{~km}^{2}$ and are managed as one entity by the Tanzania Wildlife Management Authority (TAWA). The eastern boundary of the RNP is marked by the following community-managed wildlife management areas, which were established on communal land: $777 \mathrm{~km}^{2}$ Matumizi Bora ya Malihai Idodi na Pawaga (MBOMIPA), $913 \mathrm{~km} 2$ Uhifadhi na Matumizi Endelevu ya Maliasili Rujewa na Wanging'ombe (UMEMARUWA), and $315 \mathrm{~km}^{2}$ Waga. Wildlife management areas are unique features of Tanzania's conservation landscape. They were established to promote a sustainable program involving local communities in wildlife protection and its economic benefits. In both the national park and the game reserves, human residency, cultivation, livestock grazing, and logging are prohibited [45]. However, the main difference between the national park and the game reserves is their utilization. Harvesting, that is, trophy hunting, is the main form of tourism in the game reserves and wildlife management areas, whereas only photographic tourism and game viewing are allowed in the national park.

The unprotected communal lands surrounding the RNP and RKMGR are important for wildlife during critical seasons and are utilized as dispersal areas, ecological networks, and wildlife migratory corridors [46]. However, these areas have experienced substantial land use disturbances due to immigration and population growth, which interfere with conservation efforts. To study the vegetation disturbance in the surroundings of the PA, we divided the surroundings into five zones (see Figure 1b).

The climate of the study area is semi-arid to arid. Rainfall is highly variable but typically peaks from December-January and March-April, with an average annual value of $873 \mathrm{~mm}$. The highest elevation is $2386 \mathrm{~m} \mathrm{[47]} \mathrm{and} \mathrm{the} \mathrm{landscape} \mathrm{is} \mathrm{mostly} \mathrm{covered} \mathrm{with}$ Somalia-Masai Vachellia-Cammiphora deciduous bushland. The western part is dominated by thickets of Zambezian Miombo Vachellia woodlands [48], which provide habitat to numerous wildlife species. Based on the definition provided in the literature [49-51], we refer to the structure of the natural vegetation cover in this area as savannah, which is characterized by continuous grassland and discontinuous tree canopies. Wildlife species in the area include African elephants (Loxodonta africana africana), a variety of antelope species such as duikers (Cephalophinae spp.) and impalas (Aepyceros melampus), hippopotami (Hippopotamus 
amphibius), greater kudus (Tragelaphus strepsiceros), Cape buffalos (Syncerus caffer), bush pigs (Potamochoerus larvatus), and olive baboons (Papio anubis). The predominant carnivores include lions (Panthera leo), leopards (Panthera pardus), African wild dogs (Lycaon pictus), spotted hyenas (Crocuta crocuta), black backed jackals (Canis mesomelas), and Nile crocodiles (Crocodylus niloticus) [52]. Additionally, the PA harbors large populations of bird species.

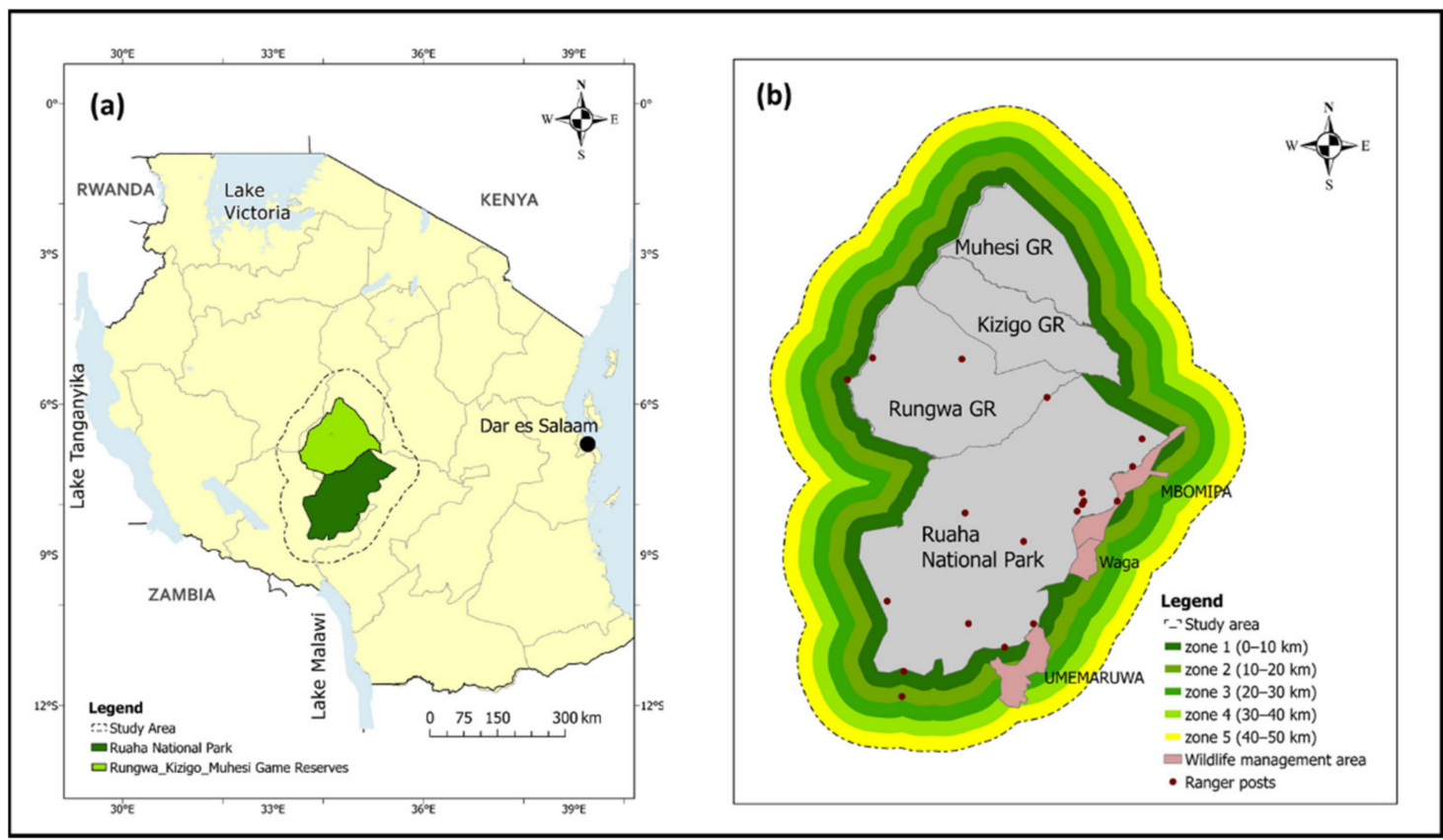

Figure 1. (a) Study area marked by the dashed line and (b) analyzed zones adjacent to the PA. The darker shades indicate zones within 0-10 km and the lighter shades represent zones within the ranges of 10-20, 20-30, 30-40, and 40-50 km from the PA boundary. GR: game reserve.

The main ethnic groups occupying the land adjacent to the RNP and RKMGR include Hehe, Bena, Maasai, Barbaig, Sukuma, and Gogo. The key socioeconomic activities are primarily subsistence agriculture and pastoralism, practiced by $60 \%$ and $33 \%$ of the population, respectively [44]. Farms are cultivated using hand hoes or ox plows and the average farm size is $12,000 \mathrm{~m}^{2}$ [53]. The savannah has been affected by increased human activity and has experienced a rapid agricultural expansion over the last two decades. This has led to the disruption of the migratory corridor [42] and the shrinking of habitat for species with large home ranges, such as African elephants, thus resulting in human-wildlife conflicts [54].

\subsection{Image Preparation}

The workflow adapted for this study was based on the LandTrendr approach [22]. A rigorous time-series segmentation algorithm was recently implemented in a cloudcomputing platform, that is, the high-performance Google Earth Engine (GEE) [55]. A total of 594 level-1 surface reflectance (L1T) Landsat TM/ETM+/OLI images from 2000 to 2019 were acquired from the USGS archive. The study area is covered by eight Landsat WRS-2 scenes (Path/Row: 168/64, 168/65, 168/66, 169/64, 169/65, 169/66, 170/64 and $170 / 65)$. A predetermined window filter corresponding to the vegetation growing season (December 1 to February 28) in the Southern Hemisphere was applied to the eight WRS-2 tiles to minimize the effects of phenological variations. All acquired L1T images were readyto-use cloud-masked surface reflectance images using CFMASK [56]. The difference among the spectral characteristics of the acquired images is small but significant: a Landsat 8/OLI image has a 12-bit radiometric resolution, whereas Landsat 5 TM and 7/ETM+ images have an 8-bit radiometric resolution. We adapted previously suggested harmonization 
transformation functions [57] to improve the temporal continuity between the sensors by normalizing the reflectance. Subsequently, 20 annual medoid composites were created for the study period, which consisted of all minimal cloud cover observations within the maturity season of the vegetation in the region, as previously demonstrated [58]. As the growing season in the study area across the year is divided, the composite was labelled using the post-divide year. Finally, for each composite, LandTrendr was applied to the NBR [59] as well as to the components of tasseled-cap wetness (TCW), brightness (TCB), and greenness (TCG) [60].

\subsection{Conceptual Model of Vegetation Changes}

In this study, contiguous habitats of wildlife were defined based on the natural vegetation cover (savannah) within the legal boundaries of the PA, migratory corridors, and dispersal areas in the surrounding zones. Evidence of wildlife outside the PA was provided in previous studies $[42,61]$. The natural vegetation around the PA has been disturbed or totally removed due to land clearing for the expansion of cultivated land, overgrazing, and firewood extraction [62]. This disturbance has resulted in mixed spatiotemporal patterns of savannah changes. Figure 2 shows the conceptual model of the two patterns of savannah change over time. The results of previous studies [24,63-65] demonstrated the high sensitivity of the NBR and its suitability in capturing vegetation trends over time. Hence, the NBR was used in this study to detect changes in the savannah.

a)

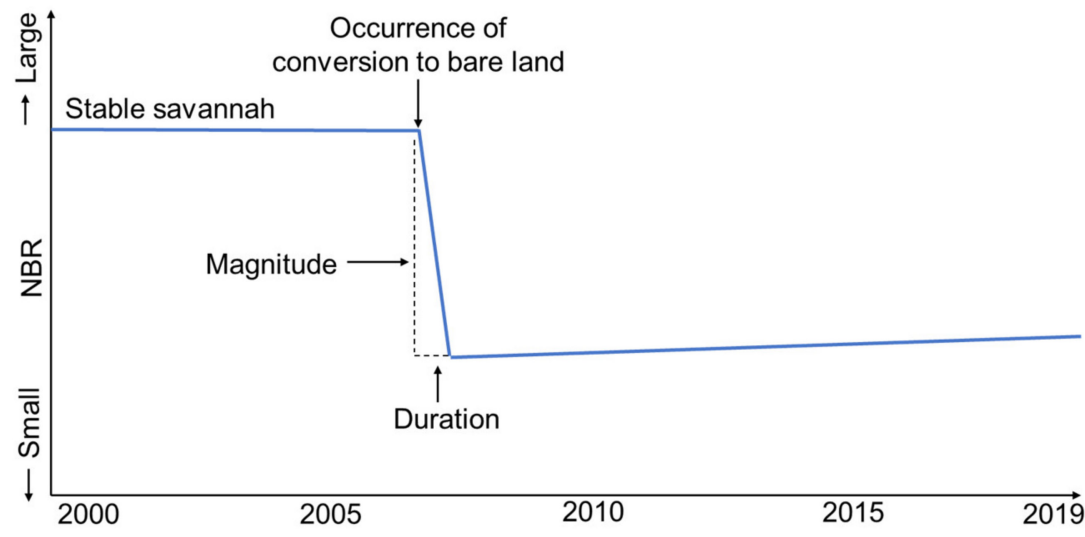

b)

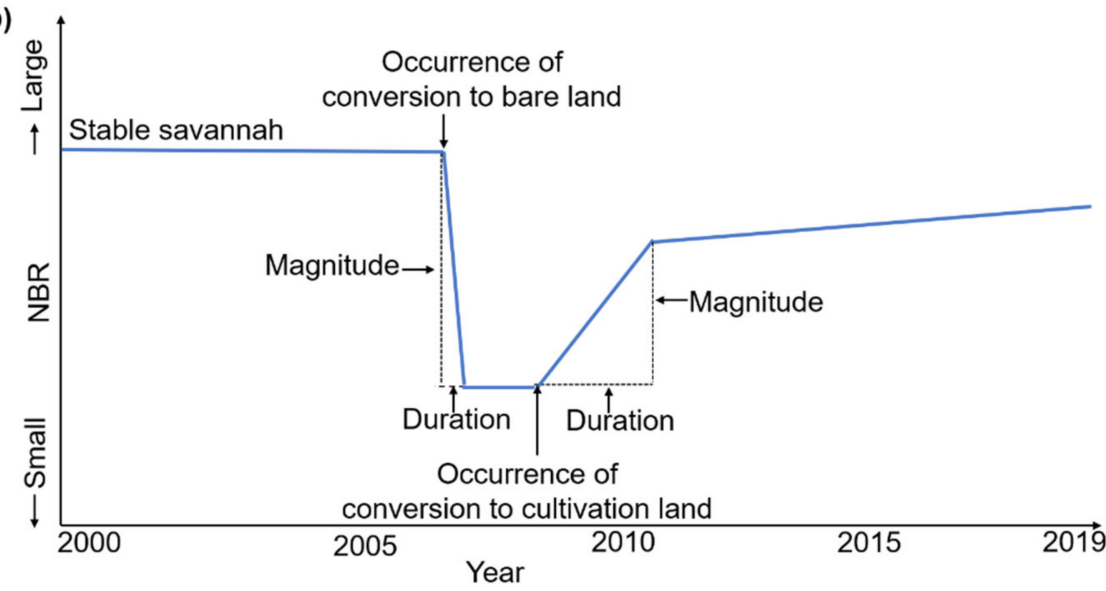

Figure 2. Conceptual models of the trajectories of the vegetation indicator (NBR) around the PA modified from Kennedy et al. [64]. The blue line represents the dynamic trajectory of the changed savannah area. The shape of the trajectory depends on the causes and progression of the change. (a) NBR trajectory for the conversion to bare land; and (b) NBR trajectory for the conversion to cultivated land. 
The NBR can be calculated as follows [66]:

$$
N B R=\frac{N I R-S W I R}{N I R+S W I R},
$$

where NIR and SWIR refer to near-infrared (highly reflective, healthy vegetation) and shortwave-infrared (highly reflective on bare earth, scarred vegetation). The NBR ranges from -1 to +1 . Healthy stable vegetation has a very high reflectance in the NIR region and low reflectance in the SWIR portion of the spectrum. Therefore, a high NBR value indicates healthy vegetation, whereas a low value indicates a lack of vegetation.

To thoroughly study the NBR signatures depending on disturbance, we sampled more than 300 points representing savannah conversion in the study area. The savannah was largely converted into either cultivated or bare land. The annual spectral vegetation index (NBR) within the savannah was generally higher and more stable before any disturbance. When the savannah is converted to bare land, the NBR value (Figure $2 \mathrm{a}$ ) sharply declines and remains at a low level. When the savannah is converted into cultivated land, the initially higher $N B R$ value rapidly drops and eventually stabilizes at a relatively lower value than before (Figure $2 \mathrm{~b}$ ). These trajectories are also affected by climatic factors, soil, satellite image quality, and phenology. However, anthropogenic activities, such as agriculture, lead to the disturbance or complete removal of the savannah cover. Thus, anthropogenic activities are the greatest driving forces of savannah disturbance. Note that in the proposed trajectories in Figure 2, the change occurrence, magnitude, and duration are examples of the year in which the change was detected, the severity of the disturbance reflected by the variation of the NBR between events, and the elapsed time of the change occurrence, respectively.

\subsection{Mapping Savannah Changes Using the LandTrendr Algorithm}

The LandTrendr routine was based on a previously established code [55] and the algorithm is automated. Temporal segmentation is used to detect abrupt short-term and gradual long-term changes for each pixel in two main phases. First, the algorithm establishes a vertex that describes the temporal breakpoints per year. It then removes yearto-year noise (outliers) from the time series. The LandTrendr algorithm uses regression and point-to-point lines to identify the best-fitting straight-line trajectories across the vertices based on the determined control parameters using a previously described approach [55]. The final output of this procedure is a fitted trajectory (Figure 2) for each pixel within the processing area, which was either a single segment if the pixel exhibited a stable or gradual change over the time series or multiple segments representing significant changes over time. The maximum segment number was controlled by the set parameters and we attempted to set up six parameters in this study. We extracted the greatest change segment from the trajectory of each pixel which was fitted to the spectral indices. From this segment, a set of three metrics was derived, namely the duration, rate of change, and the magnitude of disturbance. For the quantification of disturbance severity, we used the relative spectral change magnitude. Severity was calculated as the difference between the magnitudes at the start and at the end divided by the starting magnitude [64].

We defined the control parameters to enhance the quality of change detection. We sampled a number of savannah conversion occurrences and repeatedly tested a number of different combinations to obtain ideal parameter values. We first applied the LandTrendr algorithm to the NBR time series and then to the tasseled-cap components of TCW, TCB, and TCG, as described in the literature [63]. The use of the tasseled-cap components provided additional bands with more detailed spectral information for the distinction between cultivated land and stable savannah. In order to filter out commission errors introduced by the LandTrendr algorithm, we used a set of metrics derived from the greatest disturbance change segment for $N B R$, and the measure of signal-to-noise as described in [67] to classify each pixel. The NBR characteristics were carefully studied (Figure 3 ) and showed that the savannah area has the highest $N B R$, ranging from $0.22-0.60$. Upon the conversion to bare 
land, the NBR sharply dropped to below 0.20 and the values for cultivated land ranged from 0.22 to 0.34 . In this study, we assumed that the savannah did not return to its original state once converted to cultivated land.

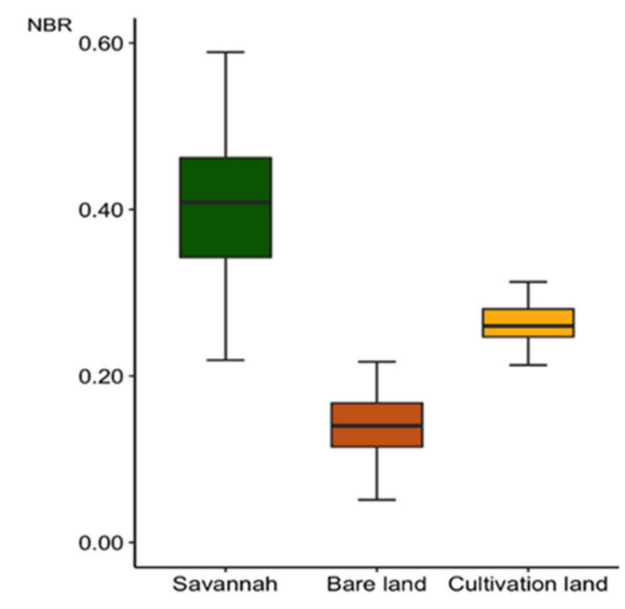

Figure 3. Spectral values of the normalized burnt ratio $(N B R)$ for sample pixels $(n=300)$ of savannah, bare land, and cultivated land in the study area.

\section{Results}

\subsection{Accuracy Assessment}

The LandTrendr algorithm can detect changes at high temporal frequencies. However, it is difficult to find appropriate reference data to precisely assess its spatiotemporal accuracy as highlighted in previous studies [22]. Independently available datasets with a higher spatial resolution and temporal frequency than Landsat imagery within the time coverage of the Landsat archive is not available [22,67]. To understand the occurrence of spatiotemporal disturbances, Landsat imagery data are the primary reference used for validation [22]. Therefore, we used Google Earth images with a high spatial resolution to validate these changes (Figure 4). Although these images have a high spatial resolution, the temporal frequency differs from that of Landsat data. To validate the detected savannah changes, we first collected the reference data by selecting 500 sample pixels from the entire study area using a stratified random sampling method, similar to a previous approach [18]. We visually tracked the changes of each reference point by comparing all 20 annual Landsat composites with high-resolution Google Earth imagery. Based on the reference points, we were able to determine where and when changes occurred in these pixels. Only the largest change was considered in the case of multiple changes within a single pixel. The change occurrence information was used as a reliable reference for the validation of accuracy [68]. Several reference points were disregarded because of poor image quality. A total of 471 reference pixels were used for further comparisons, among which 242 represented change events and 229 referred to areas with persistent vegetation cover throughout the analysis period (2000-2019).

The results of the accuracy assessment (Table 1) reveal a producer accuracy of $91.14 \%$ and a user accuracy of $80.17 \%$ for the changed pixels, with an overall accuracy of $86.37 \%$. The relatively lower user accuracy suggests a higher quantity of commission errors compared with omission errors. Omission errors might be due to either partly changed pixels as they are difficult to detect due to variations in the magnitude, or pixels of low-severity disturbance that could not be distinguished from noise. Commission errors are mainly due to clouds, images missed more than three times (consecutively), and the low temporal frequency of the time series. The high producer and user accuracies of the detection of change by the LandTrendr algorithm confirm that this method is robust. 


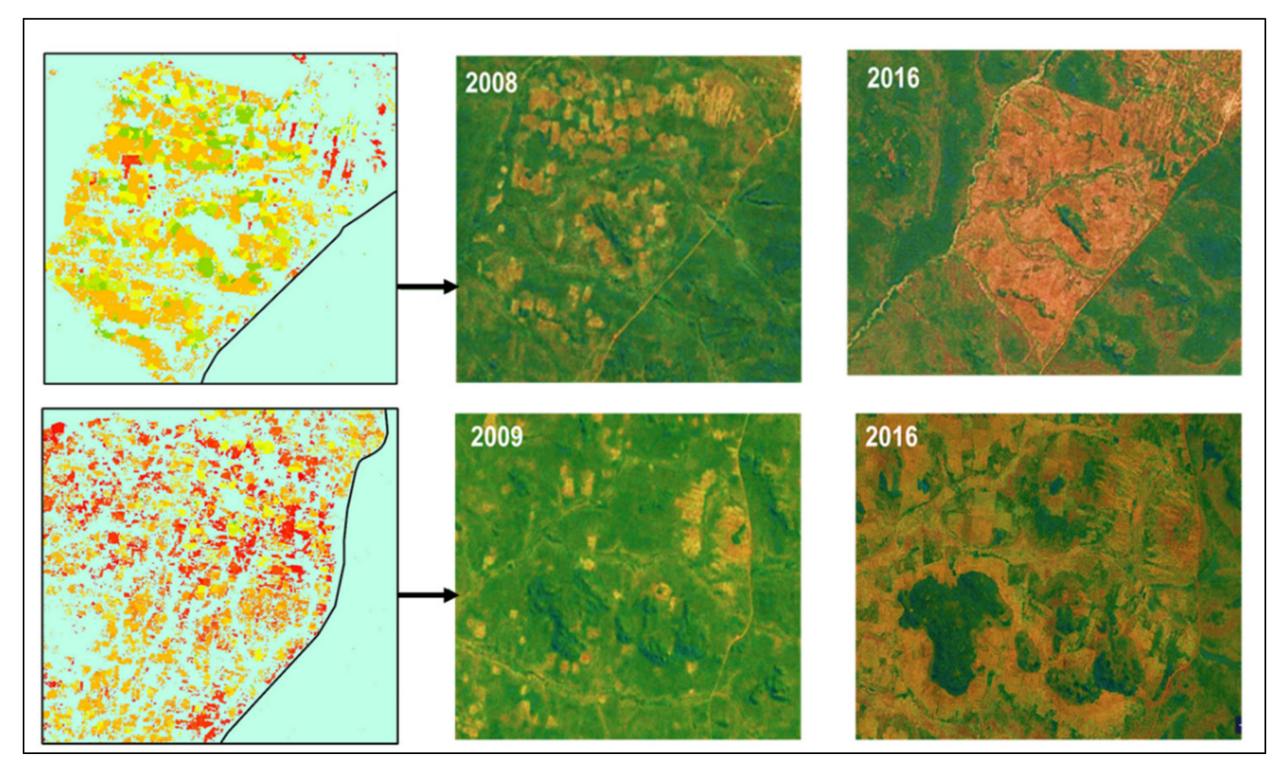

Figure 4. Examples of disturbance in Google Earth images showing the pre-disturbance (2008/2009) and post-disturbance (2016) of the savannah. Currently, the vegetation is being cleared due to farming.

Table 1. Accuracy assessment of the change detection.

\begin{tabular}{ccccc}
\hline & Changed Pixel & Stable Pixel & Total & User Accuracy (\%) \\
\hline Changed pixel & 194 & 48 & 242 & 80.17 \\
Stable pixel & 17 & 212 & 229 & 92.58 \\
Total & 211 & 260 & & 86.37 \\
Producer & 91.94 & 81.54 & & Overall \\
accuracy (\%) & & & & \\
\hline
\end{tabular}

\subsection{Spatial and Temporal Patterns of Savannah Disturbance}

The vegetation disturbance is visualized in Figure 5 as a gradient according to occurrence years, representing the spatial and temporal distribution of savannah changes from to 2000-2019. During the analysis period 2000-2019, a savannah area of $18,022.59 \mathrm{~km}^{2}$ was disturbed within the Ruaha-Rungwa landscape (Table 2). The vegetation change analysis in the study area highlights the contrast between PAs and unprotected areas. Throughout the monitoring period, the surrounding zones exhibited a significant amount of disturbance, whereas minimal changes of $1.12 \%$ and $0.75 \%$ were observed within the boundaries of the RNP and RKMGR, respectively (Table 2). This indicates that the advancement of savannah disturbance is spatially heterogeneous and discontinuous within the study area (Figure 5).

We analyzed the changes in each surrounding zone to understand the relationship between the disturbance occurrence and distance to the boundaries of the RNP and RKMGR. Overall, the areas closer to the boundary of the RKMGR (0-10 and 10-20 km) exhibit widely distributed savannah disturbances of $57.10 \%$ and $52.58 \%$, respectively (Table 2). In contrast, dispersed minimum disturbances of $6.11 \%$ and $12.20 \%$ were observed closer to the boundaries of the RNP (0-10 and 10-20 km), respectively, implying reduced changes to the savannah during the detection period (Table 2). The southern part of the RuahaRungwa landscape, that is, the RNP, was still relatively connected to its surroundings and showed less disturbance, whereas in a large part of the western RKMGR, a sharp edge was developed between the PA and adjacent lands with large disturbance patches. A varying pattern of disturbance events associated with the conversion of savannah was pronounced in all surrounding zones. 


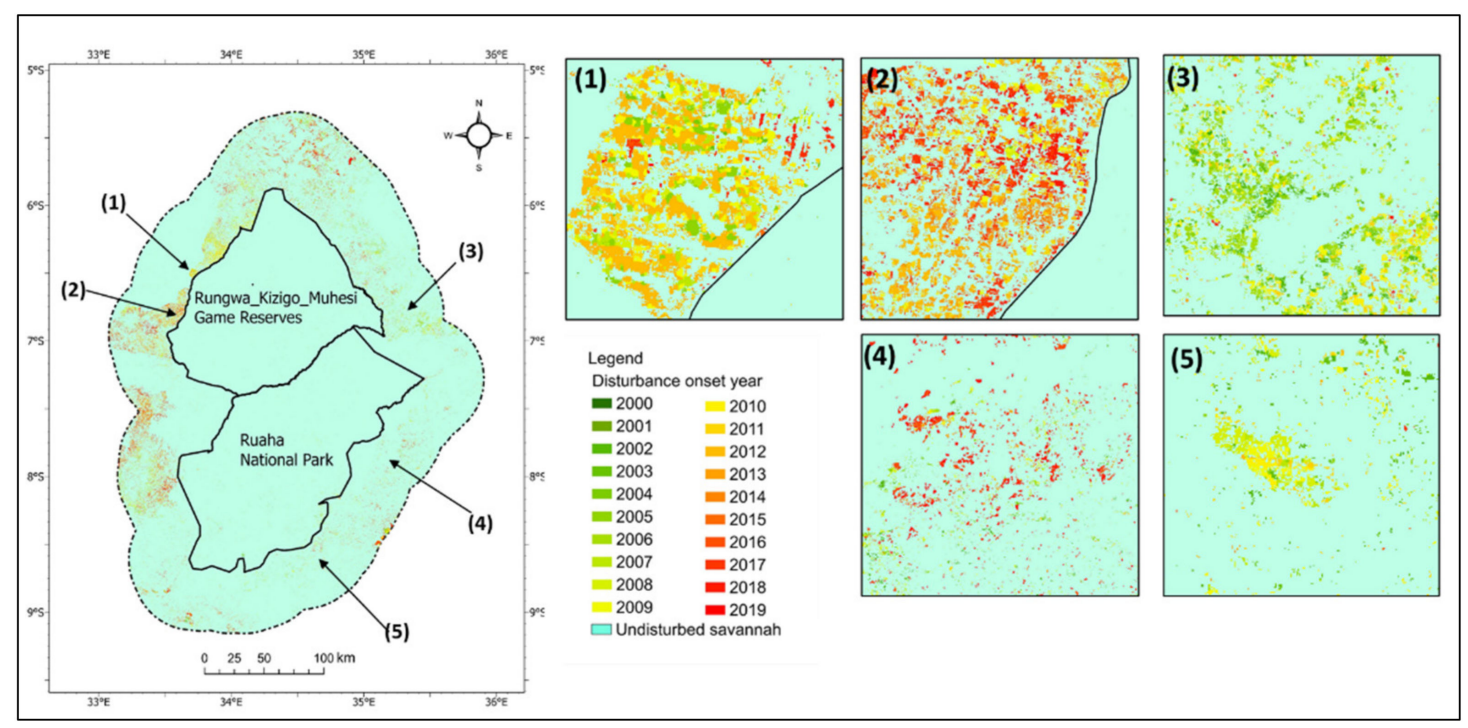

Figure 5. Spatial pattern and the year of the change occurrence in the Ruaha-Rungwa landscape from 2000 to 2019: (1), (2), (3), (4), and (5) are magnifications of prevalent disturbances; and (1) and (2) are the areas that were used for the accuracy assessment (highlighted in Figure 4).

Table 2. Changed savannah areas in each zone during the monitoring period (2000-2019).

\begin{tabular}{|c|c|c|c|c|c|c|}
\hline & \multicolumn{3}{|c|}{ RKMGR } & \multicolumn{3}{|c|}{ RNP } \\
\hline & $\begin{array}{c}\text { Total Area } \\
\text { Analyzed }\left(\mathbf{k m}^{2}\right)\end{array}$ & $\begin{array}{c}\text { Changed Area } \\
\left(\mathrm{km}^{2}\right)\end{array}$ & $\begin{array}{c}\text { Percentage } \\
\text { Change }\end{array}$ & $\begin{array}{c}\text { Total Area } \\
\text { Analyzed }\left(\mathbf{k m}^{2}\right)\end{array}$ & $\begin{array}{c}\text { Changed Area } \\
\left(\mathrm{km}^{2}\right)\end{array}$ & $\begin{array}{l}\text { Percentage } \\
\text { Change }\end{array}$ \\
\hline Within the PA & 17340.00 & 130.68 & $0.75 \%$ & 20226.00 & 227.21 & $1.12 \%$ \\
\hline $\begin{array}{c}\text { Zone } 1 \\
(0-10 \mathrm{~km})\end{array}$ & 4690.6 & 2673.59 & $57.10 \%$ & 5680.0 & 340.66 & $6.11 \%$ \\
\hline $\begin{array}{c}\text { Zone } 2 \\
(10-20 \mathrm{~km})\end{array}$ & 4792.5 & 2491.52 & $52.58 \%$ & 5572.5 & 668.75 & $12.20 \%$ \\
\hline $\begin{array}{c}\text { Zone } 3 \\
(20-30 \mathrm{~km})\end{array}$ & 4954.3 & 1337.41 & $35.79 \%$ & 5811.6 & 1336.89 & $23.75 \%$ \\
\hline $\begin{array}{c}\text { Zone } 4 \\
(30-40 \mathrm{~km})\end{array}$ & 5182.9 & 1865.19 & $36.25 \%$ & 6097.9 & 2499.18 & $41.05 \%$ \\
\hline $\begin{array}{c}\text { Zone } 5 \\
(40-50 \mathrm{~km})\end{array}$ & 5415.6 & 1949.95 & $36.48 \%$ & 6254.94 & 2501.88 & $40.67 \%$ \\
\hline Total & & $10,448.34$ & & & 7574.59 & \\
\hline
\end{tabular}

The disturbance patterns significantly changed between 2000 and 2019. However, the trends differed depending on the management type of the respective parts of the landscape. The most significant disturbances were observed during the second decade of the study period. The western side of the PA is the hotspot of the most recent changes (Figure 5). Overall, in the early monitoring period (2000-2008), minimal disturbance was detected in the surrounding areas of the RNP and RKMGR. The high spike in the disturbed savannah area across the landscape between 2011 and 2012 coincides with the severe drought that occurred in East Africa [67], confirming the ability of Landtrendr to capture natural disturbances.

\subsection{Vegetation Cover Changes in the Surrounding Areas of the PAs}

The annual disturbance extent around the PAs is reflected by the trends of each analysis area, as shown in Figure 6. The disturbance trends significantly changed between 2000 and 2019. However, the trends differed across the Ruaha-Rungwa landscape (Figure 6). Hot spots of disturbed areas were observed in zones closer to the RKMGR and included the largest disturbed area. Over the entire study period of 2000-2019, the highest annual 
disturbance rates of up to $2.86 \%$ and $2.63 \%$ (Figure 7) were observed in the zones adjacent to the boundary of the RKMGR (0-10 and 10-20 km), respectively. In contrast, the zones farthest from the boundary exhibit relatively lower conversion rates of between $1.81 \%$ and $1.82 \%$ (Figure 7). In the surrounding areas of the RNP, the lowest conversion rates in the zones closer to the boundary ( $0-10$ and $10-20 \mathrm{~km}$ ) ranged from $0 \%$ to $0.29 \%$.
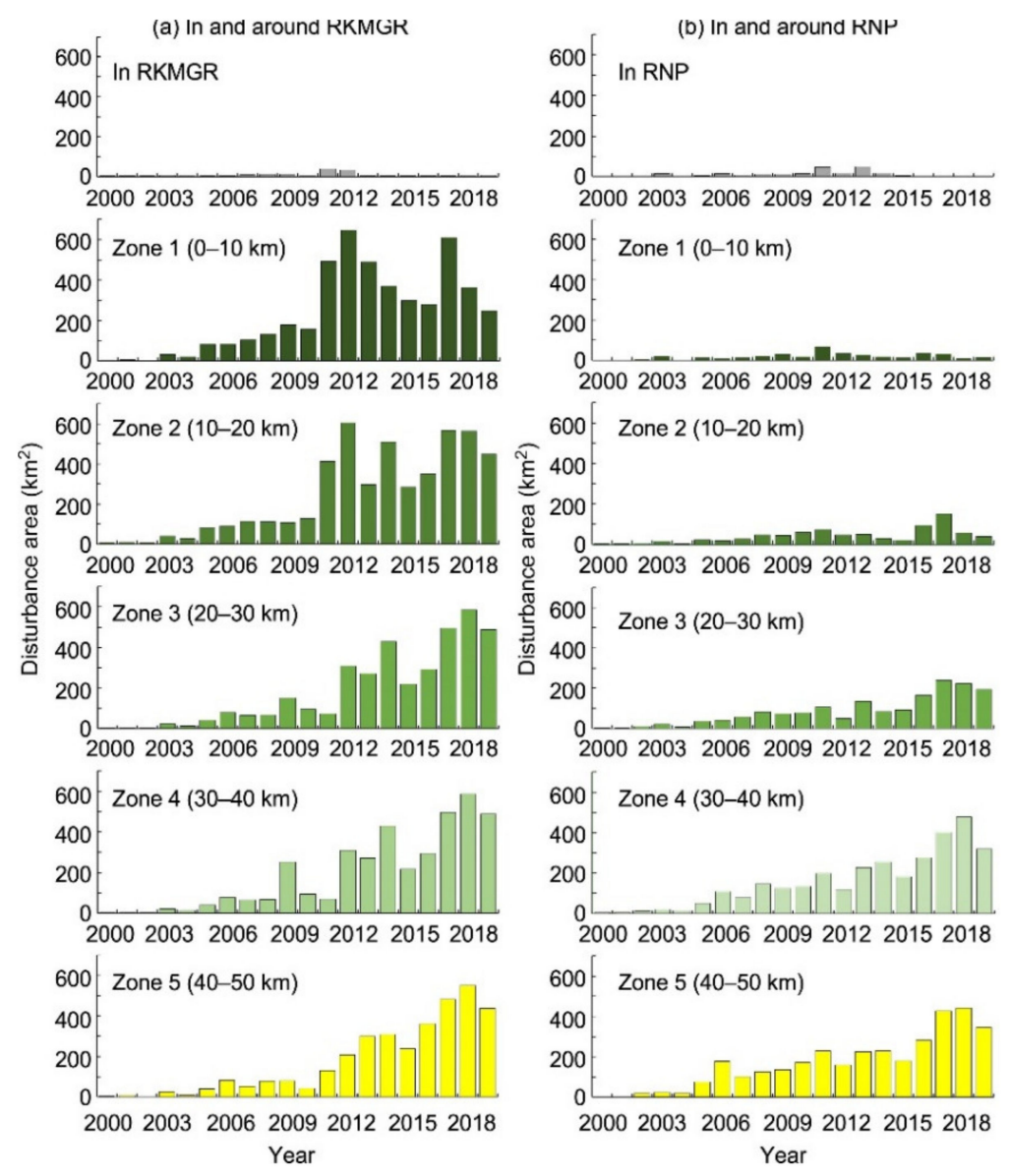

Figure 6. (a) Trends of the savannah disturbance area within the PA and in the five zones surrounding the RKMGR from 2000 to 2019; and (b) the trends in the savannah disturbance area within the PA and in the five zones surrounding the RNP from 2000 to 2019.

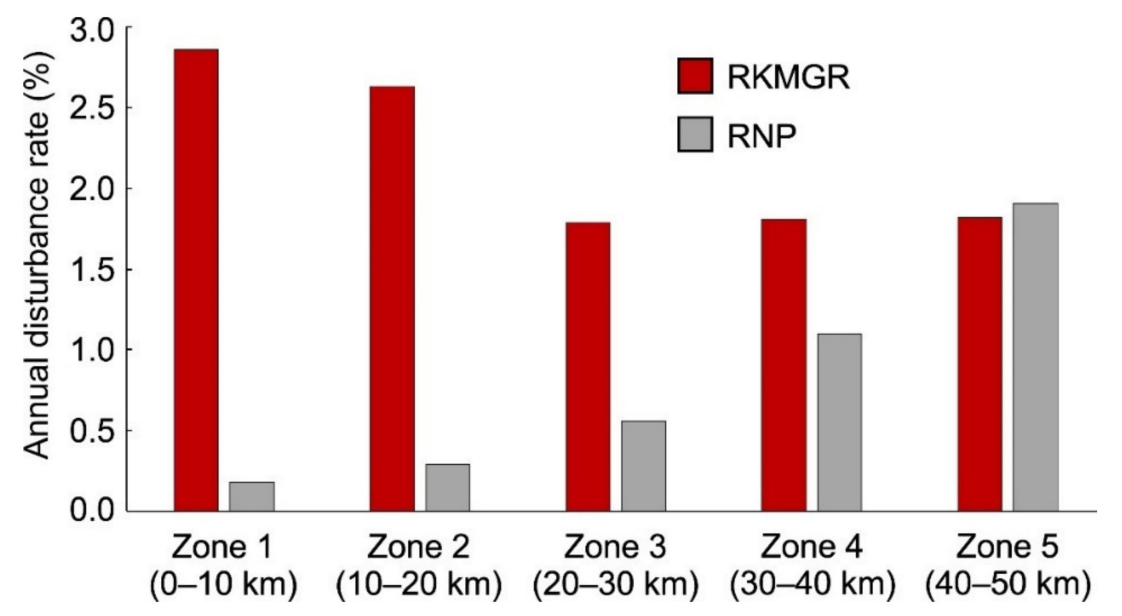

Figure 7. Annual disturbance rate for each zone surrounding the RKMGR and RNP. 


\subsection{Characterization of Vegetation Disturbance}

We obtained a continuous disturbance severity value, ranging from 0 to 1 (Figure 8). The severity measure denotes the probability of the total removal of the savannah cover, where 0 indicates no change in the dominant vegetation cover and 1 indicates total savannah loss. Within the Ruaha-Rungwa landscape, the disturbance severity ranged from 0.22 to 1.00 (median 0.79 ). Changed pixels exhibited an average disturbance severity of 0.65 . This indicates the dominance of high-severity disturbances in more than half of the disturbed pixels in the landscape. The disturbance severity measure can be used to effectively distinguish between undisturbed savannah (no loss of vegetation cover), partial disturbance, and the complete loss of savannah cover due to, for example, agricultural practices. Based on this measure, an on-going disturbance severity was detected across the Ruaha landscape with an uneven distribution across (Figure 8).

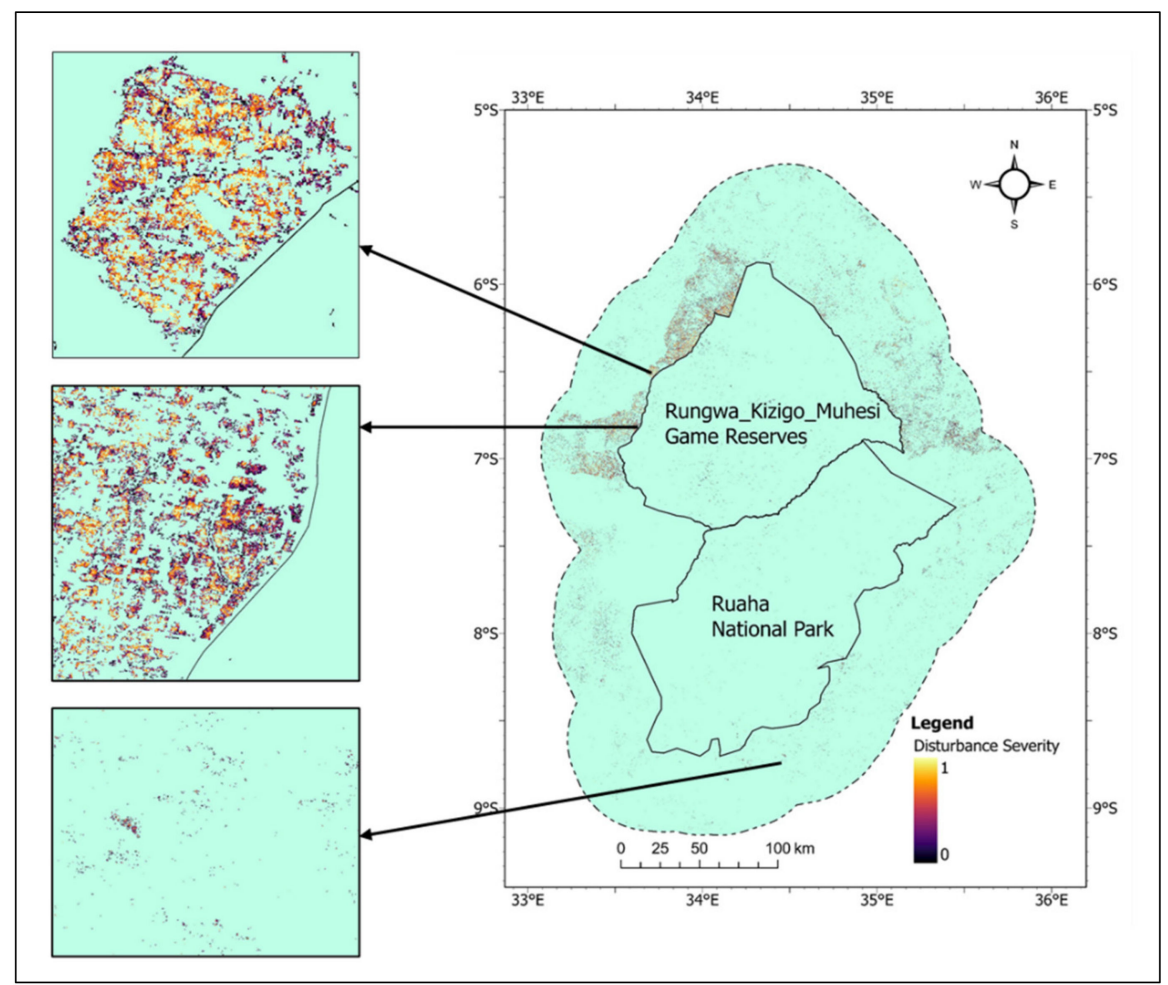

Figure 8. Disturbance severity in and around the Ruaha-Rungwa landscape. Magnifications of the prevalent regions of savannah conversion in the RKMGR and in the surroundings of the RNP.

Due to the development of farmlands and the nature of the vegetation cover of closed savannah woodlands and acacia thickets, disturbance results in large patches with significantly declining NBR values in the western RKMGR (Figure 8). Therefore, the severity in the surrounding zones closer to the western RKMGR tended to be higher. In contrast, the surrounding zones of the RNP exhibited a low disturbance severity with smaller disturbance patches.

\section{Discussion}

\subsection{Spatiotemporal Distribution of Vegetation Disturbance}

In this study, the patterns, severity, rate, and extent of the savannah disturbance prevailing in the Ruaha-Rungwa landscape were quantitatively characterized. Different parts of the landscape display varying patterns of savannah disturbance. Zones closer to the RKMGR exhibited the highest increase (Figure 7). The analysis of the disturbance severity implies significant vegetation degradation in the zones around the RKMGR compared with the zones surrounding the RNP (Figure 8). The spatial disturbance distribution maps 
(Figures 5 and 8) revealed that extensive vegetation disturbance is more pronounced along the western side of the RKMGR than on the eastern side. This spatial differentiation might be affected by various biophysical characteristics of the location, namely, agroecological zones [69] (Figure 9a), soil, and climate [70]. The agroecological zones are based on elevation classes derived from the Shuttle Radar Topography Mission (SRTM), with a $30 \mathrm{~m}$ spatial resolution [71]. The western side of the PA is preferentially used for agricultural land because of its favorable altitude range for crops, including maize, sorghum, sunflower, millet, and tobacco, which have high yields at medium (1000-1500 m) and high (1400-2000 m) altitudes [72]. The western and northern areas in the surroundings of the RKMGR are dominated by an elevation conducive for agriculture (>1000 m; Figure 10). The eastern side is preferred by pastoralists because of the low altitude and availability of extensive wetlands for grazing (Figures 9 and 10).

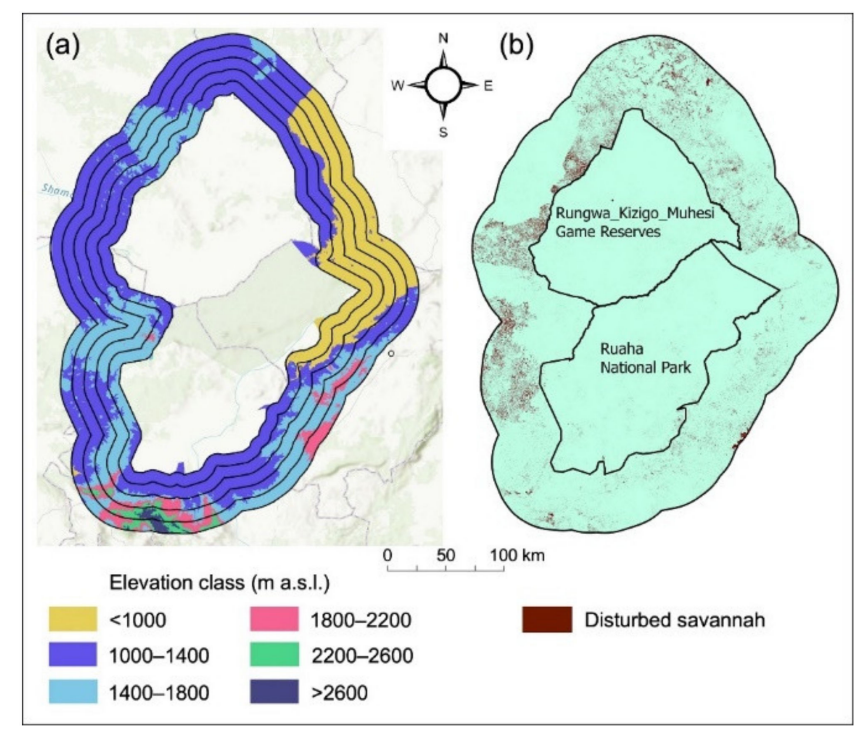

Figure 9. (a) Elevation map of the surroundings of the PA based on SRTM DEM and (b) vegetation disturbance occurrence in the area surrounding the PAs.

We mainly observed continuously increasing disturbance rates around the zones adjacent to the RKMGR (0-10 and 10-20 km; Figure 6a). Zones farther from the RKMGR boundary (30-40 and 40-50 km) partially fall within the protected Nyahua Mbuga forest reserves, which explains the low disturbance. The observed disturbance severity varies, with large disturbance patches in the western RKMGR. The high disturbance severity may be exacerbated by the conversion of savannah cover due to agricultural activities, and the widening of disturbance patches might be due to the expansion of cultivation land in the surrounding areas of the PA. The minimum severity observed across the landscape may reflect the selective cutting of trees for firewood and construction, which leads to the loss of valuable tree species such as African blackwood Dalbergia and Pterocarpus angolensis $[73,74]$. Savannah generally occurs in low-fertility soils, which hinders intensive agriculture. Therefore, resident communities embrace destructive forms of farming and pastoralism activities [74], generally at the expense of the natural habitat. Such vegetation losses in the surroundings of PAs are critical because wide-ranging species, including African elephants, require vast areas to guarantee long-term survival, which may not be provided by PAs alone [75].

The vegetation cover within the borders of the PA fares better than that in surrounding buffer zones, as suggested by its undisturbed state, indicating that management practices implemented in the PA are effective. This observation is supported by a previous study that showed that habitat degradation in the surrounding unprotected areas across the landscape is increasing compared with the PAs [76]. Land use changes at the edges of 
the PA play fundamental roles in explaining the observed disturbance patterns due to the shapes and linear edges of the disturbance patches.

(a) Surrounding of the RKMGR

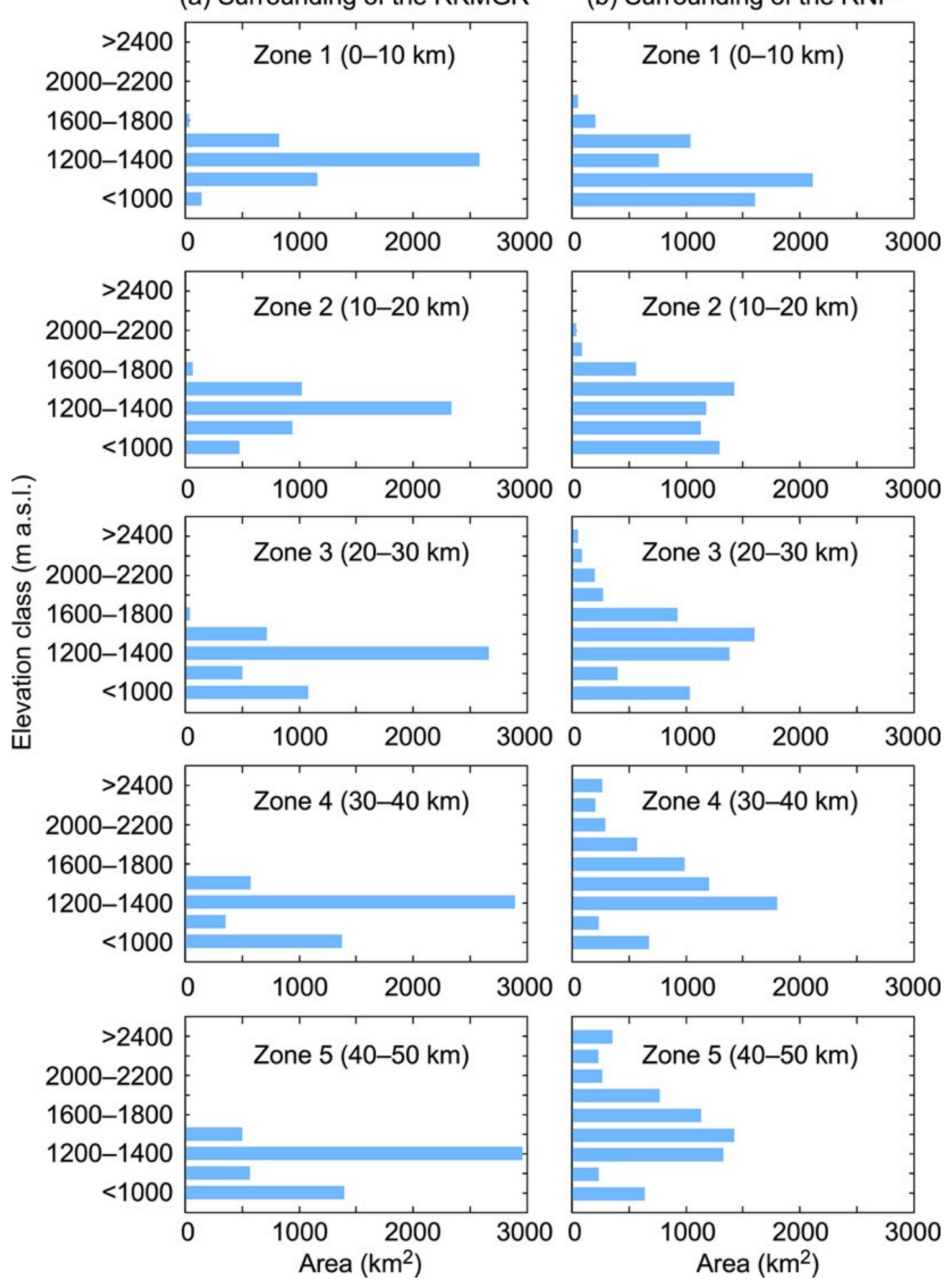

Figure 10. (a,b) Distribution of elevation across five zones (as shown in Figure 9) in the surroundings of the Ruaha-Rungwa landscape.

\subsection{Relationship between Vegetation Disturbance and Wildlife Conservation}

The disturbance maps (Figures 5 and 8 ) highlight the variations in the disturbance patterns and extent across the Ruaha-Rungwa landscape. Although the savannah and overall biophysical environment certainly partially explain the variability in the disturbance patterns [77], differences in management approaches play central roles in explaining the patterns observed in the surroundings of the RKMGR and RNP. The area adjacent to the boundary of the RKMGR is not under legal protection; thus, it is vulnerable to conversion to other land uses that are not compatible with the conservation purpose of the PA.

The increased disturbance at the edges of PAs reflects the high potential for humanwildlife conflicts. Areas adjacent to the border should be considered less desirable by agro-pastoralists because of severe human-wildlife conflicts [43,54], which account for crop losses as well as livestock and human deaths. In contrast, we observed an increase in human activities close to the border of the RMKGR. However, the opposite trend was observed close the border of the RNP, as shown in Figure 7. The trend around the RMKGR is likely due to high poverty rates: $11.3 \%$ of the residents in the villages surrounding the RMKGR live below the food poverty threshold and $33.3 \%$ live below the basic need threshold [78]. This can be explained by the large livelihood dependence of these communities on the resources from the RMKGR, which involves the illegal harvesting of wildlife resources [44] 
as many people near the RMKGR consume bushmeat and sell it to supplement their income. The major key indicator of bushmeat hunting is the distance from the PA $[79,80]$. In the RKMGR, only three rangers patrol the PA (Figure 1b), which suggests that rangers in the RKMGR face challenges in effectively protecting the area against illegal hunting.

In recent decades, the surroundings of PAs in Tanzania have been severely affected by the transition of mobile pastoralists to a sedentary lifestyle [81], and the immigration of small-scale farmers has resulted in the conversion of natural vegetation into cropland [79]. The RNP is partially shielded by community-based initiatives, including three wildlife management areas, namely MBOMIPA, Waga, and UMEMARUWA (Figure 1b) in which villagers have purposely set aside a piece of land for sustainable conservation and the utilization of wildlife resources [82]. The creation of the three wildlife management areas adjoining the RNP on the eastern side increases the distance between the PA and the potential disturbances and limits the edge effect (Figure 5).

The recent increases in anthropogenic disturbances in the surrounding areas of PAs observed in this study agree with results published by Estes et al. (2012) [83] who reported growing savannah conversion towards the edges of the Serengeti ecosystem as a result of increased anthropogenic activities at an annual rate of $2.3 \%$. The vegetation disturbance detected in the surrounding zones of the Ruaha-Rungwa landscape has gradually increased, especially in the latter half of the study period (Figure 6), which might be a result of increased human activities at the expense of the savannah. The patterns we observed are supported by the population increase near the PA (Figure S1) because of the economic benefits provided by the ecosystem [4]. This highlights the lack of pronounced agricultural farmlands in the study area at the beginning of the study period, whereas dominant agricultural expansion was observed at the end of the monitoring period. In accordance with previous findings [4], the average human population growth rates at the edges of PAs in Africa and Latin America are approximately double the average rural growth rates, indicating that PAs attract rather than repel human settlements, because of the opportunities they provide. The analysis of the disturbance rates throughout the study period further supports the pattern of human pressure at the edges of PAs (Figure 7).

However, the expansion of agricultural activities at the edges of the PA with a dense elephant population has led to intense human-elephant conflicts and severe damages and losses as well as negative attitudes toward wildlife conservation in the surrounding communities [84]. The number of human-elephant conflicts has increased, particularly near the borders of the ecosystem [54,61]. The Ruaha-Rungwa landscape currently hosts the largest population of elephants in Tanzania, with an extensive forage range stretching beyond the boundaries of the PA into the surrounding zones.

In the future, the edges of the PA will likely be engulfed by the increasing vegetation disturbance due to the conversion of the remaining natural habitat into cultivated land. Therefore, appropriate, broad-reaching, and collaborative conservation plans that involve engagement with the surrounding community's must be established. The results of this study inform conservation stakeholders about the pattern of advancing habitat disturbance including (1) the spatiotemporal extents that they should focus on and (2) the concentration of conservation efforts in the critical habitat in the surrounding areas of the PA.

\subsection{Utilizing LandTrendr for the Assessment of Vegetation Disturbance and Limitations of This Study}

The application of the LandTrendr algorithm and GEE to monitor vegetation disturbance has several advantages. First, the platform can be used to manage time-series satellites and conduct cloud computing [85] at high speeds. Thus, LandTrendr can provide near-real-time vegetation changes. The method is robust and can be used to consistently and comprehensively analyze changes across large areas using the Landsat archive. In addition, the algorithm can detect the history of each pixel. Furthermore, monitoring can easily be extended sequentially as human activities progress in the future. Therefore, it will play a major role in current decision-making as well as in understanding future vegetation dynamics. Second, the method uses the Landsat archive, which is cost-free and 
consistent. Therefore, it can be widely applied, especially in PAs with limited access to satellite data. Third, the implementation of the GEE facilitates the accessibility to a wider range of users including managers with low expertise, limited experience, and insufficient financial capacity.

However, this approach has several limitations. The selection of vegetation index change dynamics may vary depending on the landscape and distinction between natural and human disturbance. Therefore, further research should be conducted to collect supplementary information based on optimum vegetation indices for savannah landscapes and in situ field surveys including the application of unmanned aerial vehicles for very high-resolution data acquisition. In addition, only the largest disturbance per pixel that occurred throughout the 20-year monitoring period was considered in this study. Therefore, several disturbances might have been missed. In addition, the analysis of satellite data for heterogeneous landscapes, such as savannah, can be susceptible to noise based on the inaccurate detection of low-severity disturbances. Despite these limitations, we are confident that the comprehensive spatial analysis of the patterns and trends of savannah disturbance is a critical step towards understanding the contemporary changes in the Ruaha-Rungwa landscape.

\section{Conclusions}

In this study, prevailing savannah disturbance trends in the Ruaha-Rungwa landscape were analyzed for a period of two decades (2000-2019), a dataset which is of importance for monitoring habitat dynamics. The results show that the disturbance patterns and severity in the surrounding areas of the RKMGR and RNP differ spatially. The spatial pattern of the savannah disturbance significantly declines in the natural habitat in the surroundings of the RKMGR compared with the RNP. The surrounding zones closer to the RKMGR experienced the greatest disturbance, most likely due to the expansion of agricultural activities. The smaller disturbance in the surrounding zones closer to the RNP may be due to the ongoing incorporation of parts of the surrounding areas into community-based conservation schemes. The temporal distribution indicates an increased disturbance in the latter decade (2010-2019), probably reflecting the continuous prevalence of anthropogenic activities. Generally, savannah within the PA fares better than the surrounding landscape and the least disturbance severity was observed within the borders of the RKMGR and RNP, suggesting that habitat in the PA is effectively conserved. Spatial savannah changes derived from the LandTrendr time-series approach provide relevant spatiotemporal references for understanding vegetation cover changes in large areas and thus are of significance for biodiversity conservation. Similar studies can be adopted in other large PAs, particularly in developing countries that are experiencing significant land use change with limited access to spatial data. The results of this study provide insights into patterns of habitat change over time, which can be used by PA managers, policy makers, planners, and scientists in planning and achieving sustainable conservation.

Supplementary Materials: The following are available online at https:/ /www.mdpi.com/article/10 $.3390 / \mathrm{rs} 13091800 / \mathrm{s} 1$, Figure S1: Human population distribution in the districts around the RuahaRungwa landscape.

Author Contributions: Conceptualization and writing A.W.K.; supervision and original draft preparation, T.W.; software and data preparation, M.K.; methodology, M.B.C. All authors contributed to the editing and discussion of the manuscript. All authors have read and agreed to the published version of the manuscript.

Funding: This research received no external funding.

Acknowledgments: The authors would like to thank TAWIRI and TANAPA for providing GIS data and Ramadhan Mohamed for sharing a wealth of background information about the RuahaRungwa landscape.

Conflicts of Interest: The authors declare no conflict of interest. 


\section{References}

1. Geldmann, J.; Barnes, M.; Coad, L.; Craigie, I.D.; Hockings, M.; Burgess, N.D. Effectiveness of terrestrial protected areas in reducing habitat loss and population declines. Biol. Conserv. 2013, 161, 230-238. [CrossRef]

2. Nelson, A.; Chomitz, K.M. Effectiveness of Strict vs. Multiple Use Protected Areas in Reducing Tropical Forest Fires: A Global Analysis Using Matching Methods. PLoS ONE 2011, 6, e22722. [CrossRef]

3. Le Saout, S.; Hoffmann, M.; Shi, Y.; Hughes, A.; Bernard, C.; Brooks, T.M.; Bertzky, B.; Butchart, S.H.M.; Stuart, S.N.; Badman, T.; et al. Protected areas and effective biodiversity conservation. Science 2013, 342, 803-805. [CrossRef] [PubMed]

4. Wittemyer, G.; Elsen, P.; Bean, W.T.; Burton, A.C.O.; Brashares, J.S. Accelerated human population growth at protected area edges. Science 2008, 321, 123-126. [CrossRef] [PubMed]

5. Ellis, E.C. Anthropogenic transformation of the terrestrial biosphere. Trans. R. Soc. A 2011, 369, 1010-1035. [CrossRef] [PubMed]

6. Hansen, A.J.; DeFries, R. Ecological mechanisms linking protected areas to surrounding lands. Ecol. Appl. 2007, 17, 974-988. [CrossRef] [PubMed]

7. DeFries, R.; Hansen, A.; Turner, B.L.; Reid, R.; Liu, J. Land Use Change around Protected Areas: Management To Balance Human Needs and Ecological Function. Ecol. Appl. 2007, 17, 1031-1038. [CrossRef] [PubMed]

8. DeFries, R.; Hansen, A.; Newton, A.C.; Hansen, M.C. Increasing isolation of protected areas in tropical forest over the past twenty years. Ecol. Appl. 2005, 15, 19-26. [CrossRef]

9. Liu, J.; Linderman, M.; Ouyang, Z.; An, L.; Yang, J.; Zhang, H. Ecological degradation in protected areas: The case of Wolong nature reserve for giant pandas. Science 2001, 292, 98-101. [CrossRef] [PubMed]

10. Fischer, J.; Lindenmayer, D.B. Landscape modification and habitat fragmentation: A synthesis. Glob. Ecol. Biogeogr. 2007, 16, 265-280. [CrossRef]

11. McIntyre, S.; Hobbs, R. A framework for conceptualizing human effects on landscapes and its relevance to management and research models. Conserv. Biol. 1999, 13, 1282-1292. [CrossRef]

12. Betts, M.G.; Wolf, C.; Ripple, W.J.; Phalan, B.; Millers, K.A.; Duarte, A.; Butchart, S.H.M.; Levi, T. Global forest loss disproportionately erodes biodiversity in intact landscapes. Nature 2017, 547, 441-444. [CrossRef] [PubMed]

13. Ellis, E.C.; Antill, E.C.; Kreft, H. All Is Not Loss: Plant Biodiversity in the Anthropocene. PLoS ONE 2012, 7, e30535. [CrossRef]

14. Laurance, W.F.; Sayer, J.; Cassman, K.G. Agricultural expansion and its impacts on tropical nature. Trends Ecol. Evol. 2014, 29, 107-116. [CrossRef] [PubMed]

15. Allen, C.D.; Macalady, A.K.; Chenchouni, H.; Bachelet, D.; McDowell, N.; Vennetier, M.; Kitzberger, T.; Rigling, A.; Breshears, D.D.; Hogg, E.H.; et al. A global overview of drought and heat-induced tree mortality reveals emerging climate change risks for forests. For. Ecol. Manag. 2010, 259, 660-684. [CrossRef]

16. Turner, M.G. Disturbance and landscape dynamics in a changing world. Ecology 2010, 91, 2833-2849. [CrossRef]

17. Johnstone, J.F.; Allen, C.D.; Franklin, J.F.; Frelich, L.E.; Harvey, B.J.; Higuera, P.E.; Mack, M.C.; Meentemeyer, R.K.; Metz, M.R.; Perry, G.L.W.; et al. Changing disturbance regimes, ecological memory, and forest resilience. Front. Ecol. Environ. 2016, 14, 369-378. [CrossRef]

18. Zhu, Z.; Woodcock, C.E. Continuous change detection and classification of land cover using all available Landsat data. Remote Sens. Environ. 2014, 144, 152-171. [CrossRef]

19. Nagendra, H.; Lucas, R.; Honrado, J.P.; Jongman, R.H.G.; Tarantino, C.; Adamo, M.; Mairota, P. Remote sensing for conservation monitoring: Assessing protected areas, habitat extent, habitat condition, species diversity, and threats. Ecol. Indic. 2013, 33, 45-59. [CrossRef]

20. Willis, K.S. Remote sensing change detection for ecological monitoring in United States protected areas. Biol. Conserv. 2015, 182, 233-242. [CrossRef]

21. Huang, C.; Goward, S.N.; Masek, J.G.; Thomas, N.; Zhu, Z.; Vogelmann, J.E. An automated approach for reconstructing recent forest disturbance history using dense Landsat time series stacks. Remote Sens. Environ. 2010, 114, 183-198. [CrossRef]

22. Kennedy, R.E.; Yang, Z.; Cohen, W.B. Detecting trends in forest disturbance and recovery using yearly Landsat time series: 1. LandTrendr - Temporal segmentation algorithms. Remote Sens. Environ. 2010, 114, 2897-2910. [CrossRef]

23. Yang, Y.; Erskine, P.D.; Lechner, A.M.; Mulligan, D.; Zhang, S.; Wang, Z. Detecting the dynamics of vegetation disturbance and recovery in surface mining area via Landsat imagery and LandTrendr algorithm. J. Clean. Prod. 2018, 178, 353-362. [CrossRef]

24. Nguyen, T.H.; Jones, S.D.; Soto-Berelov, M.; Haywood, A.; Hislop, S. A spatial and temporal analysis of forest dynamics using Landsat time-series. Remote Sens. Environ. 2018, 217, 461-475. [CrossRef]

25. Zhu, L.; Liu, X.; Wu, L.; Tang, Y.; Meng, Y. Long-Term Monitoring of Cropland Change near Dongting Lake, China, Using the LandTrendr Algorithm with Landsat Imagery. Remote Sens. 2019, 11, 1234. [CrossRef]

26. Liu, S.; Wei, X.; Li, D.; Lu, D. Examining Forest Disturbance and Recovery in the Subtropical Forest Region of Zhejiang Province Using Landsat Time-Series Data. Remote Sens. 2017, 9, 479. [CrossRef]

27. Stuart Chapin, F.; Matson, P.A.; Vitousek, P.M. Principles of Terrestrial Ecosystem Ecology; Springer: New York, NY, USA, 2012; ISBN 9781441995049.

28. Newmark, W.D. Isolation of African protected areas. Front. Ecol. Environ. 2008, 6, 321-328. [CrossRef]

29. Lorenzen, E.D.; Heller, R.; Siegismund, H.R. Comparative phylogeography of African savannah ungulates. Mol. Ecol. 2012, 21, 3656-3670. [CrossRef] 
30. Andela, N.; Liu, Y.Y.; van Dijk, A.I.J.M.; de Jeu, R.A.M.; McVicar, T.R. Global changes in dryland vegetation dynamics (1988-2008) assessed by satellite remote sensing: Comparing a new passive microwave vegetation density record with reflective greenness data. Biogeosciences 2013, 10, 6657-6676. [CrossRef]

31. Campo-Bescós, M.A.; Muñoz-Carpena, R.; Kaplan, D.A.; Southworth, J.; Zhu, L.; Waylen, P.R. Beyond Precipitation: Physiographic Gradients Dictate the Relative Importance of Environmental Drivers on Savanna Vegetation. PLoS ONE 2013, 8, e72348. [CrossRef] [PubMed]

32. Estes, L.D.; Searchinger, T.; Spiegel, M.; Tian, D.; Sichinga, S.; Mwale, M.; Kehoe, L.; Kuemmerle, T.; Berven, A.; Chaney, N.; et al. Reconciling agriculture, carbon and biodiversity in a savannah transformation frontier. Philos. Trans. R. Soc. B Biol. Sci. 2016, 371, 20150316. [CrossRef] [PubMed]

33. Jenkins, C.N.; Joppa, L. Expansion of the global terrestrial protected area system. Biol. Conserv. 2009, 142, 2166-2174. [CrossRef]

34. Kendall, C.J. The spatial and agricultural basis of crop raiding by the Vulnerable common hippopotamus Hippopotamus amphibius around Ruaha National Park, Tanzania. Oryx 2011, 45, 28-34. [CrossRef]

35. Bartlam-Brooks, H.L.A.; Bonyongo, M.C.; Harris, S. Will reconnecting ecosystems allow long-distance mammal migrations to resume? A case study of a zebra Equus burchelli migration in Botswana. Oryx 2011, 45, 210-216. [CrossRef]

36. Serneels, S.; Lambin, E.F. Impact of land-use changes on the wildebeest migration in the northern part of the Serengeti-Mara ecosystem. J. Biogeogr. 2002, 28, 391-407. [CrossRef]

37. Ogutu, J.O.; Owen-Smith, N.; Piepho, H.P.; Said, M.Y. Continuing wildlife population declines and range contraction in the Mara region of Kenya during 1977-2009. J. Zool. 2011, 285, 99-109. [CrossRef]

38. Tanzania Program > Landscapes > Ruaha/Katavi. Available online: https://tanzania.wcs.org/landscapes/ruaha-katavi.aspx (accessed on 9 January 2021).

39. Fratkin, E. East African Pastoralism in Transition: Maasai, Boran, and Rendille Cases. Afr. Stud. Rev. 2001, 44, 1-25. [CrossRef]

40. Rufino, M.C.; Thornton, P.K.; Ng'ang'a, S.K.; Mutie, I.; Jones, P.G.; van Wijk, M.T.; Herrero, M. Transitions in agro-pastoralist systems of East Africa: Impacts on food security and poverty. Agric. Ecosyst. Environ. 2013, 179, 215-230. [CrossRef]

41. Newmark, W.D.; Manyanza, D.N.; Gamassa, D.-G.M.; Sariko, H.I. The Conflict between Wildlife and Local People Living Adjacent to Protected Areas in Tanzania: Human Density as a Predictor. Conserv. Biol. 1994, 8, 249-255. [CrossRef]

42. Kwaslema, M.H.; Robert, D.F.; Jafari, R.K.; Eivin, R. Assessing crop and livestock losses along the Rungwa-Katavi Wildlife Corridor, South-Western Tanzania. Int. J. Biodivers. Conserv. 2017, 9, 273-283. [CrossRef]

43. Abade, L.; Macdonald, D.W.; Dickman, A.J. Assessing the relative importance of landscape and husbandry factors in determining large carnivore depredation risk in Tanzania's Ruaha landscape. Biol. Conserv. 2014, 180, 241-248. [CrossRef]

44. Hariohay, K.M.; Ranke, P.S.; Fyumagwa, R.D.; Kideghesho, J.R.; Røskaft, E. Drivers of conservation crimes in the Rungwa-KizigoMuhesi Game Reserves, Central Tanzania. Glob. Ecol. Conserv. 2019, 17, e00522. [CrossRef]

45. URT. The Wildlife Policy of Tanzania. 1998, pp 1-39. Available online: http://www.tzonline.org/pdf/wildlifepolicy.pdf. (accessed on 22 March 2021).

46. Jones, T.; Bamford, A.J.; Ferrol-Schulte, D.; Hieronimo, P.; McWilliam, N.; Rovero, F. Vanishing Wildlife Corridors and Options for Restoration: A Case Study from Tanzania. Trop. Conserv. Sci. 2012, 5, 463-474. [CrossRef]

47. NASA JPL. NASA Shuttle Radar Topography Mission Global 1 Arc Second; NASA JPL: Pasadena, CA, USA, 2019. Available online: https:/ / doi.org/10.5067/MEaSUREs/SRTM/SRTMGL1.003 (accessed on 13 October 2019).

48. Sosovele, H.; Ngwale, J. Socio-Economic Root Causes of the Loss of Biodiversity in the Ruaha Catchment Area. 2002. Available online: https: / / wwfeu.awsassets.panda.org/downloads/rcareportruaha.pdf (accessed on 22 March 2021).

49. Sankaran, M.; Hanan, N.P.; Scholes, R.J.; Ratnam, J.; Augustine, D.J.; Cade, B.S.; Gignoux, J.; Higgins, S.I.; Le Roux, X.; Ludwig, F.; et al. Determinants of woody cover in African savannas. Nature 2005, 438, 846-849. [CrossRef] [PubMed]

50. Cahoon, D.R.; Stocks, B.J.; Levine, J.S.; Cofer, W.; O’Neill, K.P. Seasonal distribution of African savanna fires. Nature 1992, 359, 812-815. [CrossRef]

51. Ratnam, J.; Bond, W.J.; Fensham, R.J.; Hoffmann, W.A.; Archibald, S.; Lehmann, C.E.R.; Anderson, M.T.; Higgins, S.I.; Sankaran, M. When is a "forest" a savanna, and why does it matter? Glob. Ecol. Biogeogr. 2011, 20, 653-660. [CrossRef]

52. Nahonyo, C. Assessment of anti-poaching effort in Ruaha National Park, Tanzania. Tanzania J. Sci. 2009, 31, 13-21. [CrossRef]

53. Farm Size I Family Farming Knowledge Platform. Available online: http://www.fao.org/family-farming/data-sources/ dataportrait/farm-size/en (accessed on 18 April 2020).

54. Hariohay, K.M.; Munuo, W.A.; Røskaft, E. Human-elephant interactions in areas surrounding the Rungwa, Kizigo, and Muhesi Game Reserves, central Tanzania. Oryx 2019, 54, 612620. [CrossRef]

55. Kennedy, R.E.; Yang, Z.; Gorelick, N.; Cohen, W.B.; Healey, S. Implementation of the LandTrendr Algorithm on Google Earth Engine. Remote Sens. 2018, 10, 691. [CrossRef]

56. Hafemann Fragal, E.; Sanna, T.; Silva, F.; Márcia, E.; De, L.; Novo, M. Reconstructing historical forest cover change in the Lower Amazon floodplains using the LandTrendr algorithm. Acta Amaz. 2016, 46, 13-24. [CrossRef]

57. Roy, D.P.; Kovalskyy, V.; Zhang, H.K.; Vermote, E.F.; Yan, L.; Kumar, S.S.; Egorov, A. Characterization of Landsat-7 to Landsat-8 reflective wavelength and normalized difference vegetation index continuity. Remote Sens. Environ. 2016, 185, 57-70. [CrossRef]

58. Flood, N. Seasonal composite landsat TM/ETM+ Images using the medoid (a multi-dimensional median). Remote Sens. 2013, 5 , 6481-6500. [CrossRef] 
59. Key, C.H.; Benson, N.C. LA-1 Landscape Assessment (LA) Sampling and Analysis Methods. In FIREMON: Fire Effects Monitoring and Inventory System; Lutes, D.C., Keane, R.E., Caratti, J.F., Key, C.H., Benson, N.C., Sutherland, S., Gangi, L.J., Eds.; USDA Forest Service: Washington, DC, USA, 2005.

60. Crist, E.P.; Cicone, R.C. A Physically-Based Transformation of Thematic Mapper Data-The TM Tasseled Cap. IEEE Trans. Geosci. Remote Sens. 1985, GE-22, 256-263. [CrossRef]

61. Munuo, W. Distribution Patterns of Human Elephant Conflict in Areas Adjacent to Rungwa Game Reserve, Tanzania. Master's Thesis, Norwegian University of Science and Technology, Trondheim, Norway, 2016.

62. Lobora, A.L.; Nahonyo, C.L.; Munishi, L.K.; Caro, T.; Foley, C.; Beale, C.M. Modelling habitat conversion in miombo woodlands: Insights from Tanzania. J. Land Use Sci. 2017, 12, 391-403. [CrossRef]

63. Kennedy, R.E.; Yang, Z.; Braaten, J.; Copass, C.; Antonova, N.; Jordan, C.; Nelson, P. Attribution of disturbance change agent from Landsat time-series in support of habitat monitoring in the Puget Sound region, USA. Remote Sens. Environ. 2015, 166, 271-285. [CrossRef]

64. Kennedy, R.E.; Yang, Z.; Cohen, W.B.; Pfaff, E.; Braaten, J.; Nelson, P. Spatial and temporal patterns of forest disturbance and regrowth within the area of the Northwest Forest Plan. Remote Sens. Environ. 2012, 122, 117-133. [CrossRef]

65. Hermosilla, T.; Wulder, M.A.; White, J.C.; Coops, N.C.; Hobart, G.W. Disturbance-Informed Annual Land Cover Classification Maps of Canada's Forested Ecosystems for a 29-Year Landsat Time Series. Can. J. Remote Sens. 2018, 44, 67-87. [CrossRef]

66. USGS Landsat Surface Reflectance-Derived Spectral Indices. Available online: https://www.usgs.gov/core-science-systems/nli/ landsat/landsat-surface-reflectance-derived-spectral-indices?qt-science_support_page_related_con=0\#qt-science_support_ page_related_con (accessed on 2 January 2021).

67. Cohen, W.B.; Yang, Z.; Healey, S.P.; Kennedy, R.E.; Gorelick, N. A LandTrendr multispectral ensemble for forest disturbance detection. Remote Sens. Environ. 2018, 205, 131-140. [CrossRef]

68. Huang, C.; Goward, S.N.; Schleeweis, K.; Thomas, N.; Masek, J.G.; Zhu, Z. Dynamics of national forests assessed using the Landsat record: Case studies in eastern United States. Remote Sens. Environ. 2009, 113, 1430-1442. [CrossRef]

69. Kauzeni, A.S.; Kikula, I.S.; Mohamed, S.A.; Lyimo, J.G.; Dalal-Clayton, D.B. Land Use Planning and Resource Assessment in Tanzania: A Case Study; The International Institute for Environment and Development: London, UK, 1993; ISBN 1843692023.

70. Funakawa, S.; Yoshida, H.; Watanabe, T.; Sugihara, S.; Kilasara, M.; Kosaki, T. Soil Fertility Status and Its Determining Factors in Tanzania. Soil Health Land Use Manag. 2012. [CrossRef]

71. LP DAAC-Data Citation and Policies. Available online: https://lpdaac.usgs.gov/data/data-citation-and-policies/ (accessed on 10 March 2021).

72. Croon, I.; Deutsch, J.; Temu, A.E.M. Maize Production in TAanzania's Southern Highlands: Current Status and Recommendation for the Future, Mexico, Mexico. 1984. Available online: https://repository.cimmyt.org/handle/10883/3795 (accessed on 22 March 2021).

73. Madulu, N.F. Population Dynamics and Sustainable Conservation of Protected Areas in Tanzania: The case of Swagaswaga Game Reserve in Kondoa District. In Proceedings of the 24th IUSSP Conference, Bahia, Brasil, 18-24 August 2001; Volume 2.

74. Caro, T.; Jones, T.; Davenport, T.R.B. Realities of documenting wildlife corridors in tropical countries. Biol. Conserv. 2009, 142, 2807-2811. [CrossRef]

75. Hansen, M.C.; Loveland, T.R. A review of large area monitoring of land cover change using Landsat data. Remote Sens. Environ. 2012, 122, 66-74. [CrossRef]

76. Lobora, A.L.; Nahonyo, C.L.; Munishi, L.K.; Caro, T.; Foley, C.; Beale, C.M. Efficacy of land use designation in protecting habitat in the miombo woodlands: Insights from Tanzania. bioRxiv 2017, 1-38. [CrossRef]

77. Herrero, H.; Waylen, P.; Southworth, J.; Khatami, R.; Yang, D.; Child, B. A Healthy Park Needs Healthy Vegetation: The Story of Gorongosa National Park in the 21st Century. Remote Sens. 2020, 12, 476. [CrossRef]

78. URT, The United Republic of Tanzania. SINGIDA SOCIO-ECONOMIC PROFILE; Dar es Salaam: National Bureau of Statistics. 2017. Available online: https://www.scirp.org/(S(czeh2tfqyw2orz553k1w0r45))/reference/ReferencesPapers.aspx?ReferenceID= 856838 (accessed on 22 March 2021).

79. Knapp, E.J.; Peace, N.; Bechtel, L. Poachers and Poverty: Assessing Objective and Subjective Measures of Poverty among Illegal Hunters Outside Ruaha National Park, Tanzania. Conserv. Soc. 2017, 15, 24-32. [CrossRef]

80. Loibooki, M.; Hofer, H.; Campbell, K.L.I.; East, M.L. Bushmeat hunting by communities adjacent to the Serengeti National Park, Tanzania: The importance of livestock ownership and alternative sources of protein and income. Environ. Conserv. 2002, 29, 391-398. [CrossRef]

81. 'Operation Imparnati': The sedentarization of the pastoral Maasai in Tanzania. Available online: https://www.jstor.org/stable/ 43124000?seq=1 (accessed on 28 September 2020).

82. Coppolillo, P. A Preliminary Situation Analysis for the Ruaha-Rungwa Landscape, Tanzania; Wildlife Conservation Society: Iringa, Tanzania, 2004; p. 25.

83. Estes, A.B.; Kuemmerle, T.; Kushnir, H.; Radeloff, V.C.; Shugart, H.H. Land-cover change and human population trends in the greater Serengeti ecosystem from 1984-2003. Biol. Conserv. 2012, 147, 255-263. [CrossRef]

84. Hariohay, K.M.; Fyumagwa, R.D.; Kideghesho, J.R.; Røskaft, E. Awareness and attitudes of local people toward wildlife conservation in the Rungwa Game Reserve in Central Tanzania. Hum. Dimens. Wildl. 2018, 23, 503-514. [CrossRef]

85. Gorelick, N.; Hancher, M.; Dixon, M.; Ilyushchenko, S.; Thau, D.; Moore, R. Google Earth Engine: Planetary-scale geospatial analysis for everyone. Remote Sens. Environ. 2017, 202, 18-27. [CrossRef] 